\title{
Inclusion of Moringa Oleifera Leaf Powder in Broiler Chicken Feed and its Effect on Growth Performance, Biochemical Profile and Metabolism Stimulation: Case Study of the Synthesis of Some Sulphur Compounds
}

\author{
Michelle CF Djouhou ${ }^{1 *}$, Dieudonné Nwaga ${ }^{2}$, Borelle Mafogang ${ }^{1}$ and Elie Fokou ${ }^{1}$ \\ ${ }^{1}$ Department of Biochemistry, Laboratory for Food Science and Metabolism, Faculty of Science, Cameroon \\ ${ }^{2}$ Department of Microbiology, Laboratory of Soil Microbiology, Biotechnology Centre, Cameroon
}

*Corresponding author: Michelle CF Djouhou, Department of Biochemistry, Laboratory for Food Science and Metabolism, Faculty of Science, The University of Yaoundé, Cameroon

\section{ARTICLE INFO}

Received: 蔧 June 26, 2020

Published: 幽 July 07, 2020

Citation: Djouhou MCF, Nwaga D, Mafogang B, Fokou E. Inclusion of Moringa Oleifera Leaf Powder in Broiler Chicken Feed and its Effect on Growth Performance, Biochemical Profile and Metabolism Stimulation: Case Study of the Synthesis of Some Sulphur Compounds. Biomed J Sci \& Tech Res 28(4)2020. BJSTR. MS.ID.004693.

Keywords: Moringa Oleifera; Growth Performance; Biochemical Profile; Sulphur Compounds; Broiler Chicken

\section{ABSTRACT}

In recent decades, the availability of sulphur in soil has become a limiting factor compromising plant growth and consequently affecting animal and human feeding. Moringa oleifera L. is known as one of the most useful multipurpose plants. It can be effectively utilized as food supplement and help in the management of nutrient shortage and sulphur metabolism stimulation because of its nutrient and sulphur content. The present experiment was conducted to assess the effect of Moringa leaf powder supplementation on growth performance, biochemical profile and sulphur metabolism stimulation of broiler chicken. A total of fifty-six broiler chicks of 21-day old (Cobb500) were purchased and randomly divided into four groups with two replicates containing seven birds each. Broiler starters were fed with the same starter diet; while at growth stage, four types of diet were formulated: F0 (Moringa 0\%), F1 (Moringa 2\%), F2 (Moringa 4\%) and F3 (Moringa 8\%). Chicks were fed twice a day and water was given ad libitum with the experimental diets till completion of the experiment. Collected data were analysed using ANOVA and were statistically significant if $p<0.05$. Significantly higher body weight was recorded in birds fed with F1 whereas feed conversion ratio was not significantly affected. No significant differences were observed in ash and carbohydrate content of broiler meat due to feed supplementation. The experimental diets did not considerably affect broiler chicken serum parameters, indicating no harmful or deleterious effect. Likening result to control, the consumption of Moringa leaf powder by birds significantly increased the synthesis of protein up to $30 \%$ and $38 \%$ respectively in the serum and breast meat, glutathione as well as the glutathione S-transferase activity. It may thus be concluded that, the inclusion of Moringa leaf powder in broiler chicken diet increases growth performances and metabolism stimulation through the synthesis of some sulphur compounds.

\section{Introduction}

Sulphur (S) is a non-metallic element [1] essential to living organisms because it is necessary for their growth and development. It is one of the most affluent elements on earth (after calcium and phosphorus, it is the most abundant mineral element found in human body) and serves many purposes in animals. Sulphur is a component of amino acids (methionine, cysteine, cystine, homocysteine and taurine), as well as B-vitamins (biotin and thiamine) and a number of other organic compounds [2,3]. It is an important component of healthy cartilage and as a part of the specific amino acids, it is a protein structure key. Taking into consideration these functions, it is important to get sulphur at recommended dietary levels to meet the needs of the animals. However, in recent decades, the availability of sulphur in soil has 
become a limiting factor compromising plant growth [4,5] and consequently affecting animal and human feeding. Sulphur is available to animal in their diets, derived almost exclusively from proteins since elemental sulphur in water and feed is not a readily available source for animals. Rich sources of quality protein for the body are mainly animal sources such as poultry [6]. Thus, poultry industry has been growing persistently over years around the globe and plays a major role in filling the gap made by world protein deficiency by increasing meat and egg annually produced [7].

Its meat is also characterized by comparatively low price, easy in portioning into many small parts and suffers no religion restriction in its consumption [8]. The major problem in poultry production is feed quality, which is low in sulphur amino acid; explaining why synthetized methionine is always added to their diet. Feed additives have been widely used not only to increase animal performance but also to stimulate the growth and feed efficiency and to improve the health and growth performance [9]; though the emergence of chemical product lead to serious threat for human health [10]. It is then important to explore the non-traditional feed resources as potential substitute which could be used in feed formulations and maintain health, productivity, and carcass quality. In the recent past, there has been great interest in the use of Moringa (Moringa oleifera) as a source of nutrient for livestock. From the Moringaceae family and also called "drumstick tree", "ben ailé", "benzolive", "moringoa" or miracle tree, Moringa is native of north-western India and widespread in tropical countries [11]. Every part of the plant, from the roots to the leaves has beneficial properties. Its various parts are used as fodder, herbal medicine, spices, food, natural coagulants, nectar for bees, fuel and fertilizer $[12,13]$. The dried, ground leaves of M. oleifera are rich in proteins, lipids, fibres, carbohydrates and minerals. Vitamins A, C and E as well as their provitamins and other antioxidants present in leaves are known to sequester free radicals and may have immunoprotective effects [14]. Moreover, Moringa oleifera leaves are very rich in sulphur amino acid (methionine and cysteine) and mineral sulphur. They contain about 5.19 and $8.96 \mathrm{mg}$ g-1 DM respectively of cysteine and methionine. Toxicity studies have shown that $M$. oleifera leaf extract has no reported significant adverse effects in humans, rats, rabbits or poultry [15-20].

All these data explain why Moringa is used to improve growth performance and enhance health of animal. Many studies have evaluated the effect of supplemented Moringa oleifera on growth, carcass and egg quality, plasma biochemistry, organ histopathological indices and intestinal morphology [21] but to our knowledge, there is no existing work on the effect of these leaves on sulphur metabolism and sulphur compound synthesis. In view of all these reports, it is then hypothesized that Moringa oleifera leaves, having a number of nutrients (specially protein), mineral nutrients and vitamins in a naturally balanced composition, may promote poultry growth and stimulate the synthesis of some sulphur compounds. Therefore, the objective of this study was to evaluate the effect of Moringa oleifera leaf powder on the stimulation of growth and the synthesis of some important sulphur compounds.

\section{Material and Methods}

\section{Experimental Site, Experimental Design and Animals}

The experiment was carried out in a henhouse in Yaoundé, Cameroon from July to October 2017. A total of fifty-six broiler chicks of 21-day old (Cobb 500) were randomly divided into four groups with two replicates containing seven birds each. The chicks were reared on wood shavings litter and the temperature of experimental house was maintained at $28^{\circ} \mathrm{C}$ till the end of trial, that is day 49. Birds in experimental groups were fed with the same diet supplemented with Moringa oleifera leaf powder at $0 \%, 2 \%$, $4 \%$ and $8 \%$. The fourth were then classified as follow

F0: Broiler chicks fed with normal diets without Moringa oleifera

F1: Broiler chicks fed with normal diets $+2 \%$ Moringa oleifera

F2: Broiler chicks fed with normal diets $+4 \%$ Moringa oleifera

F3: Broiler chicks fed with normal diets $+8 \%$ Moringa oleifera (Figure 1)

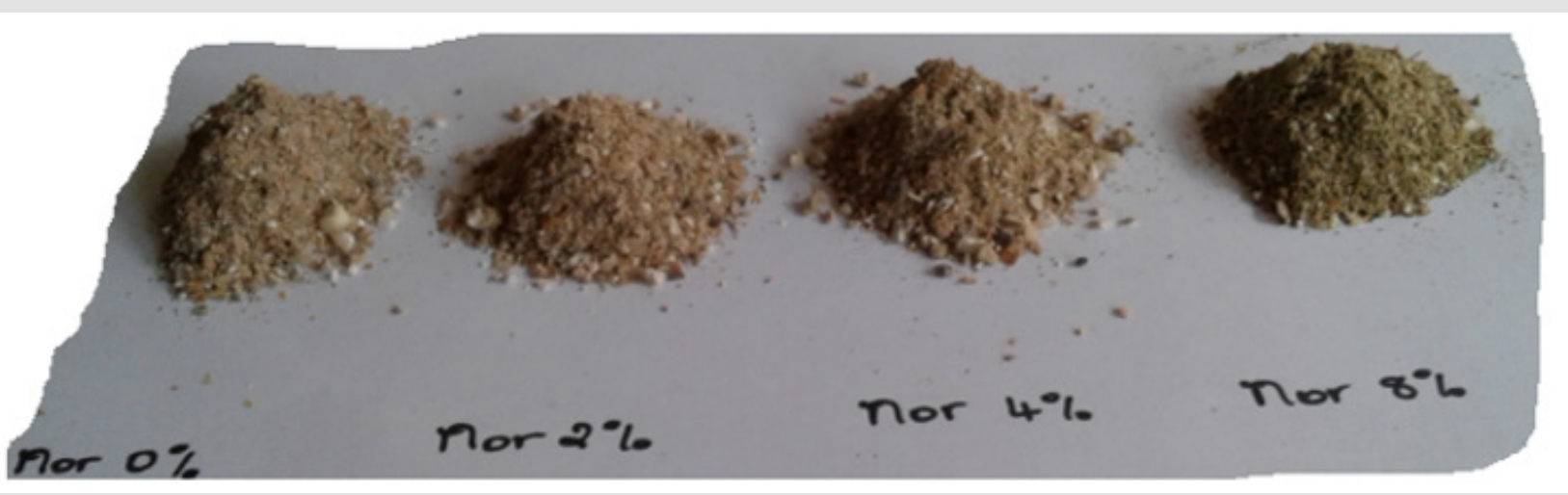

Figure 1: Experimental feed of broiler chicks. 
Moringa Oleifera Leaf Powder: To prepare Moringa leaf powder, fresh green and undamaged mature Moringa oleifera leaves were collected on over three years old trees. The leaves were dried at $55^{\circ} \mathrm{C}$ (to a relative humidity of less than $10 \%$ ), crushed to powder and sieved with $4 \mathrm{~mm}$ sieve (Figure 2).

Figure 2: Moringa oleifera leaf powder.

Feed Distribution: Feed were offered twice a day and freshwater ad libitum. The basal diet (Table 1) was formulated to meet the nutrient requirements of poultry.

Table 1: Nutritive value of animal basal diet.

\begin{tabular}{|c|c|c|}
\hline Composition & Broiler starter & Broiler growth \\
\hline Size & Fine size & Medium size \\
\hline Humidity (\%) & 11 & 21,5 \\
\hline Crude proteins (\%) & 23 & 10 \\
\hline Lipid content (\%) & 9,5 & 8 \\
\hline Minerals (\%) & 10 & 0,9 \\
\hline Lysine (\%) & 0,9 & 0,6 \\
\hline Methionine (\%) & 4,5 \\
\hline Crude fibre (\%) & 0,8 & 3050 \\
\hline ME (Kcal/kg) & 4,5 & \\
\hline
\end{tabular}

\section{Data Collection}

Feed Intake: The feed intake was determined by weighing the bucket after consumption and before the next refilling of the bucket.

Body Weights and Mortality Rate: The average group body weights and feed consumption were recorded at weekly intervals during the experimental period. Weighing was done in the morning before feeding. Body weight gains and Feed Conversion Ratio (FCR) were calculated using the above measurements. The mortality rate was recorded in different group according to distributed feed.

Blood Collection: At the end of the feeding trial (at 49 days) and after withdrawal of feed 12 hours, three birds from each replicate was randomly selected for blood and tissue sampling. Blood samples were drawn from wing veins, collected in sterilized dry centrifuge tubes without any anticoagulant and then kept at room temperature for $2 \mathrm{~h}$. After $2 \mathrm{~h}$, the tubes were centrifuged at $4000 \mathrm{rpm}$ for $15 \mathrm{~min}$ to obtain serum. The separated serum samples were kept in sterilized tubes marked and stored at $-12^{\circ} \mathrm{C}$ for biochemical analysis. After blood sampling, the birds were killed by exsanguinations of the left jugular vein. Pectoral muscle was collected, mixed, ground and used for nutritional composition analysis.

\section{Total, Reduced, Oxidised Glutathione Content and Glutathione S-Transferase Activity}

Total glutathione content was determined according to the method of Ellman as described by Weckbecker \& Cory (1988) using Ellman reagent (DTNB) or 5,5'-Dithiobis (2-nitrobenxoic acid). A calibration curve was prepared using GSH. Oxidised glutathione (GSSG) content was determined according to the method described by Anderson (1985) after elimination of reduced glutathione (GSH) using 2-vinyl-pyridine. The reduced glutathione content was calculated by the difference between the previously determined total glutathione content (GSHT $=$ GSH + GSSG) and the oxidised glutathione content (GSSG). The enzymatic activity of glutathione S-transferase was determined as described by Habig, Pabst \& Jacoby (1974) at $340 \mathrm{~nm}$ using CDNB (2,4-Dinitro-1-chlorobenzene). The 
GSH S-transferase activity was calculated as follows:

$$
G S H(n M / \min )=\frac{(A 1 / \min )-(A 0 / \min )}{\varepsilon} D
$$

Where $\mathrm{A} 1$ is the absorbance of the sample tube, $\mathrm{A} 0$, the absorbance of blank tube and $\varepsilon$ the extinction coefficient of CDNB in $\mathrm{mM}^{-1} \mathrm{Cm}^{-1}$ (9.6).

\section{Biochemical Profile: Analysis of Serum Sample}

Serum total protein, albumin, globulin and glucose were determined colorimetrically according to the methods described by Bradford for protein [22] and as described in commercial kits for the others. Lipid profile (triglycerides, total cholesterol, HDL and LDL) were determined by enzymatic colorimetric method described in a commercial kit (INMESCO Kit) as well as aspartate aminotransferase (AST), alanine aminotransferase (ALT).

\section{Water, Protein, Fat, Sugar and Thiol Content of Chicken Meat}

The water content was determined according to the method described by AOAC (1980). It is based on the mass loss of the samples at $105^{\circ} \mathrm{C}$. Total ash content was determined according to the method described by AOAC, 1980 at $550^{\circ} \mathrm{C}$. The total protein content was measured by the Kjeldahl method based on the conversion of organic nitrogen to ammonium sulphate. The nitrogen content $(\mathrm{N})$ is converted into protein using 6.25 as the converting factor [23]. The total lipid content was determined based on their differential solubility in certain organic solvents such as hexane. They are extracted in hot hexane by continuously refluxing for 12 hours [24].

The sugar content was determined by the method described by Dubois, Gilles, Hamilton, Rebers \& Smith (1956) based on dehydration followed by cyclization of C6 sugars (hexoses) and C5 (pentoses) in hot acidic medium to give respectively hydroxymethylfurfural and furfural. The latter react with phenol to give a complex with a maximum absorption at $490 \mathrm{~nm}$. Total thiols (TT) were estimated according to the method described by Sedlak \& Lindsay (1968), using Ellman's reagent with $14.15 \times 103$ (mol. $\left.\mathrm{L}^{-1}\right)^{-1} \mathrm{~cm}^{-1}$ as extinction coefficient. The glutathione content was determined as previously described.

\section{Statistical Analysis}

The data relating to various parameters were subjected to statistical analysis by using Statistical Package for Social Science version 20.0 under completely randomized design employing oneway analysis of variance. The means of different treatments were compared with Least Significance Difference test, and significance was considered at $\mathrm{p}<0.05$ level.

\section{Result and Discussion}

\section{Growth Performance}

Feed Intake: Feed consumption in each group was measured on a weekly basis and the results among the different treatment groups are presented in Figure 3. During the first week (day 21-28), feed intake was low in all group but it gradually increased to reach the highest value at week 5 (Day 49). There was no significant difference during the first week among groups ( $p>0.05)$. The prepared diets were well accepted and tolerated by the birds with the best appreciation going to F1 (Moringa 2\%) and F2 (Moringa $4 \%$ ) formulations in general. The lower feed intake during the first week as also observed by [25-30] could be due to stress associated with the introduction of new feed. After the adaptation period, feed intake progressively increased from day 28 to 49 . This can be explained by the fact that the birds have already been used to their new environment and to distributed diet, although there was a lightly significant decreasing trend of feed consumption with increased level of Moringa oleifera in the diet. Moringa oleifera leaves are rich in saponins; the latter decrease the palatability of food when added in higher quantity [31]. This can explain why feed intake decreased when Moringa oleifera leaf powder level increase in the diet. This was also reported by Gakuya et al. (2014) and the contrary was found in other studies $[32,33]$. The discrepancy in feed intake could be explained by the lower or higher energy content of Moringa leaves relative to the dietary components it replaced in different studies. Many results suggested that a supplementation level of Moringa up to $10 \%$ does not have negative effect on feed intake but lower supplementation level is suitable for their use in layers' diet [34-40].

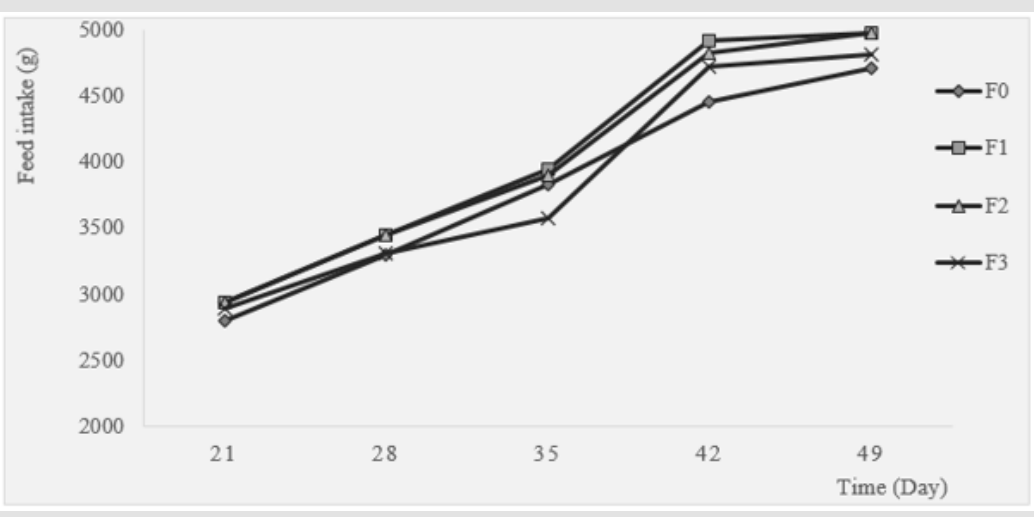

Figure 3: Effect of Moringa oleifera leaf powder supplementation on feed intake. 


\section{Body Weight (BW) and Feed Conversion Ratio (FCR)}

The effect of Moringa oleifera leaf powder supplementation on body weight and feed conversion ratio is presented in Table 2 . There was a slight weight loss in all groups during the first and second growth weeks, even though non-significant during the first ( $p>0.05$ ). The body weight continuously increased during the experimental period. At the $4^{\text {th }}$ growth week, the highest body weight belonged to F1 (Moringa 2\%) birds. The second rank was for F0 (Moringa 0\%) birds and the sequence was closed by F2 (Moringa 4\%) and F3 (Moringa 8\%). At the fifth week, F1 (Moringa 2\%) maintained his first place and F3 (Moringa 8\%) the last. The positive effects of dietary Moringa oleifera supplementation at low rate on animal performance may be attributed to Moringa content in calcium, magnesium, sodium, potassium, copper, iron, zinc, manganese, $\alpha$-tocopherol, $\beta$-carotene and ascorbic acid as well as some bioactive components. Excessive amount in diet produced adverse effects; these adverse effects of high levels of leaf meal in poultry diets could be a result of low digestibility of the protein. Furthermore, phytate content in M. oleifera might decrease availability of minerals, thus various enzymes such as phytase could be added to feed containing moringa leaves to increase phosphorus availability when used in higher quantity [41].

Table 2: Effect of Moringa oleifera leaf powder supplementation on broiler chicken body weight and feed conversion ratio.

\begin{tabular}{|c|c|c|c|c|}
\hline & Day 21-28 & Day 28-35 & Day 35-42 & Day 42-49 \\
\hline & \multicolumn{4}{|c|}{ Body weight } \\
\hline F0 & $860.20 \pm 18.31^{\mathrm{a}}$ & $1186.80 \pm 18.28^{b}$ & $1495.60 \pm 76.09^{\mathrm{ab}}$ & $1755.80 \pm 88.77^{b c}$ \\
\hline $\mathrm{F} 1$ & $836.20 \pm 16.45^{\mathrm{a}}$ & $1144.20 \pm 60.68^{\mathrm{ab}}$ & $1614.40 \pm 64.50^{\mathrm{b}}$ & $1954.80 \pm 66.60^{c}$ \\
\hline $\mathrm{F} 2$ & $831.40 \pm 9.29^{\mathrm{a}}$ & $1123.40 \pm 13.83^{\mathrm{ab}}$ & $1293.40 \pm 43.84^{\mathrm{a}}$ & $1570.80 \pm 68.28^{\mathrm{ab}}$ \\
\hline \multirow[t]{2}{*}{ F3 } & $826.00 \pm 11.61^{\mathrm{a}}$ & $1024.60 \pm 41.33^{\mathrm{a}}$ & $1326.40 \pm 102.02^{\mathrm{a}}$ & $1428.60 \pm 110.07^{a}$ \\
\hline & \multicolumn{4}{|c|}{ Feed conversion ratio } \\
\hline F0 & $2.16 \pm 0.15^{\mathrm{a}}$ & $1.96 \pm 0.03^{\mathrm{a}}$ & $2.75 \pm 0.40^{\mathrm{b}}$ & $3.64 \pm 0.56^{b}$ \\
\hline $\mathrm{F} 1$ & $2.45 \pm 0.15^{\mathrm{a}}$ & $2.46 \pm 0.34^{\mathrm{b}}$ & $1.72 \pm 0.09^{\mathrm{a}}$ & $2.59 \pm 0.09^{\mathrm{a}}$ \\
\hline $\mathrm{F} 2$ & $2.39 \pm 0.09^{\mathrm{a}}$ & $2.42 \pm 0.08^{b}$ & $6.66 \pm 2.56^{c}$ & $3.99 \pm 0.94^{\mathrm{b}}$ \\
\hline F3 & $2.36 \pm 0.11^{\mathrm{a}}$ & $3.65 \pm 0.61^{\mathrm{c}}$ & $5.91 \pm 3.98^{c}$ & $9.81 \pm 1.56^{c}$ \\
\hline
\end{tabular}

The feed conversion ratio frequently fluctuated during the growing period and the highest values were obtained at the last week with the highest FCR belonging to F3 (Moringa 8\%) birds. No statistical difference in FCR could be noticed during 21-28 days of age. This result is similar to that obtained by Panda et al. (2017). A high FCR value means that animals need to ingest large quantity of food to develop their body weight. It is then important to have lower value in case of good results. Results from Table 2 indicated that low rate of Moringa in broiler chicken reduced the FCR and increased the live body weight. This might be due the digestion stimulatory and the gastroprotective effects Moringa oleifera leaf components as reported [42-45].

\section{Mortality Rate}

Mortality rate is an important parameter to take into consideration when doing agriculture as a lucrative or nonlucrative activity. It determines the product yield and therefore the profit. The influence of Moringa leaf powder supplementation on broiler chicken mortality rate was evaluated. The only treatment where bird death was registered was F0 (Moringa 0\%) with 14.29 $\pm 0.0 \%$. It can then be concluded that Moringa oleifera in broiler diet helped to ameliorate bird health situation and reduce death incidence. This can be due to the rich nutrient profile of Moringa oleifera leaves. Actually, it has been reported that Moringa plants by their composition have growth promoter, antimicrobial and immunomodulatory properties [46]. Moreover, the phytochemical compounds of moringa possess various biological actions and confer to the plant significant medicinal properties that could be valuable [47]. Moringa leaves also have antiviral effect on Newcastle disease virus [48].

\section{Sulphur Metabolism: Protein, Total, Oxidized and Reduced Glutathione Content and GST Activity}

The effect of Moringa oleifera leaf powder incorporation on some sulphur compound synthesis was assessed in broiler serum and results are presented in Table 3. Total and reduced GSH levels were not significantly affected by feed ration. Consumption of Moringa oleifera leaf powder resulted in a decrease in serum oxidized glutathione $(\mathrm{p}<0.05)$ and a non-significant increase in reduced glutathione content ( $p>0.05)$. The reduced GSH content of broilers fed the F0 ration is insignificantly lower than that of subjects of other groups. The high content in the later, although not significant, can be explained on one hand by the fact that Moringa leaves by their composition prevent glutathione oxidation; on the other hand, they improve the absorption of amino acids such as methionine and cysteine, which are limiting factors for glutathione synthesis in the liver. These results are similar to those of Yassa \& Tohamy who showed an increase in reduced glutathione levels in rats following Moringa oleifera extract administration. 
Table 3: Effect of incorporation of Moringa oleifera leaf powder on serum total GSH, GSSG, reduced GSH, GST activity and protein content of broilers.

\begin{tabular}{|c|c|c|c|c|c|}
\hline & $\begin{array}{c}\text { Total GSH } \\
\left(\mathrm{mM} \mathrm{L}^{-1}\right)\end{array}$ & $\begin{array}{c}\text { GSSG } \\
\left(\mathrm{mM} \mathrm{L}^{-1}\right)\end{array}$ & $\begin{array}{l}\text { Reduced GSH } \\
\left(\mathrm{mM} \mathrm{L}^{-1}\right)\end{array}$ & $\begin{array}{c}{[\mathrm{GST}]^{*} 10^{-2}} \\
(\mathrm{mM} / \mathrm{min} / \mathrm{mg})\end{array}$ & Proteins (g/dl) \\
\hline F0 & $14.27 \pm 0.92^{\mathrm{a}}$ & $3.86 \pm 0.46^{\mathrm{b}}$ & $10.41 \pm 1.38^{\mathrm{a}}$ & $0.55 \pm 0.04^{\mathrm{b}}$ & $1.69 \pm 0.18^{\mathrm{a}}$ \\
\hline $\mathrm{F} 1$ & $14.76 \pm 0.22^{\mathrm{a}}$ & $2.35 \pm 0.80^{\mathrm{a}}$ & $12.42 \pm 0.58^{\mathrm{a}}$ & $0.49 \pm 0.04^{\mathrm{a}}$ & $3.07 \pm 0.09^{\mathrm{b}}$ \\
\hline $\mathrm{F} 2$ & $13.92 \pm 0.75^{\mathrm{a}}$ & $2.92 \pm 0.39^{\mathrm{a}}$ & $11.00 \pm 0.36^{\mathrm{a}}$ & $0.50 \pm 0.21^{\mathrm{a}}$ & $2.46 \pm 0.52^{\mathrm{ab}}$ \\
\hline F3 & $14.79 \pm 0.71^{\mathrm{a}}$ & $2.64 \pm 0.59^{\mathrm{a}}$ & $12.16 \pm 0.13^{\mathrm{a}}$ & $0.58 \pm 0.03^{b}$ & $2.20 \pm 0.19^{\mathrm{ab}}$ \\
\hline
\end{tabular}

Note: *Mean within the same column, having different letters are significantly different $(\mathrm{P}<0.05)$.

Glutathione is known as the most abundant low molecular weight thiol that acts crucially as a physiological antioxidant to protect biological systems $[49,50]$. The control group level obtained in this study is lower than that obtained by Wang, Cawthon \& Bottje (1998) $\left(17.0 \pm 1.1 \times 10^{-3} \mathrm{M}\right)$ in the plasma of 17 -day-old broilers. This difference could be due to the age of the animals. The glutathione level increases progressively with age in young subjects (up to 21 days of age) and then appears to decrease. In humans, this decrease may be accentuated by certain factors such as pollution, diet, physical activity, diseases, tobacco consumption. A decrease in glutathione content contributes to the oxidative stress involved in ageing and the development of many diseases. The activity of the GSH S-transferase is greater in F0 and F3 broiler serum, suggesting the presence of stressors in these groups. The GSH S-transferase content is an indicator of the oxidative status of the cell. GSH S-transferase catalyzes the detoxification of xenobiotics and reactive oxygen species with glutathione as substrate. Indeed, it catalyzes the conjugation reaction between reduced glutathione (GSH) and foreign substances (xenobiotics, carcinogens and electrophilic compounds ... etc.) with the formation of glutathione metabolites-conjugates.

Moringa oleifera leaf powder consumption resulted in an insignificant increase in serum protein content compared to the control, with a more pronounced increase in chickens receiving low Moringa leaf supplementation. These levels are within the normal range (2.4 - $4.5 \mathrm{~g} / \mathrm{dl})$ reported by Harr (2002). Serum protein levels are directly related to dietary protein intake. Indeed, the work of Samarth, Dakshinkar, Jagtap \& Bhojne (2003) showed that the incorporation of increasing leaf levels in the feed of broilers leads to an increase in serum protein content. Thus, Moringa oleifera proteins were used for the liver synthesis of chicken serum proteins. Furthermore, supplementation of broiler feed with moringa leaf Table 4: Effect of Moringa oleifera leaf powder supplementation glucose, triglycerides, HDLc, LDLc, Totalc, albumin, globulin, creatinine, and urea of broiler chicken serum.

\begin{tabular}{|c|c|c|c|c|c|c|c|c|c|c|c|}
\hline & $\begin{array}{l}\text { Glucose } \\
(\mathrm{mg} / \mathrm{dL})\end{array}$ & $\begin{array}{c}\text { Triglycerides } \\
\text { (mg/dL) }\end{array}$ & $\begin{array}{c}\text { HDLc } \\
(\mathrm{mg} / \mathrm{dL})\end{array}$ & $\begin{array}{c}\text { LDLc } \\
(\mathrm{mg} / \mathrm{dL})\end{array}$ & $\begin{array}{c}\text { Totalc } \\
(\mathrm{mg} / \mathrm{dL})\end{array}$ & $\begin{array}{c}\text { ALT } \\
(\mathrm{UI} / \mathrm{L})\end{array}$ & $\begin{array}{c}\text { AST } \\
\text { (UI/L) }\end{array}$ & $\begin{array}{l}\text { Albumin } \\
\text { (g/dL) }\end{array}$ & $\begin{array}{l}\text { Globulin } \\
\text { (g/dL) }\end{array}$ & $\begin{array}{l}\text { Creatinine } \\
\text { (mg/dL) }\end{array}$ & $\begin{array}{c}\text { Urea } \\
(\mathrm{mg} / \mathrm{dL})\end{array}$ \\
\hline F0 & $\begin{array}{c}225.09 \pm \\
4.91^{\mathrm{ab}}\end{array}$ & $167.08 \pm 5.15^{b}$ & $\begin{array}{c}77.24 \pm \\
0.28^{\mathrm{a}}\end{array}$ & $\begin{array}{c}38.30 \pm \\
1.91^{\mathrm{b}}\end{array}$ & $\begin{array}{c}148.95 \pm \\
1.15^{c}\end{array}$ & $\begin{array}{c}65.56 \pm \\
3.55^{\mathrm{b}}\end{array}$ & $\begin{array}{c}259.88 \pm \\
8.13^{d}\end{array}$ & $\begin{array}{c}2.31 \pm \\
0.26^{\mathrm{a}}\end{array}$ & $\begin{array}{c}2.38 \pm \\
0.09^{\mathrm{a}}\end{array}$ & $\begin{array}{c}0.76 \pm \\
0.02^{\mathrm{c}}\end{array}$ & $\begin{array}{c}5.85 \pm \\
0.17^{\mathrm{b}}\end{array}$ \\
\hline $\mathrm{F} 1$ & $\begin{array}{c}241.70 \pm \\
3.51^{\mathrm{b}}\end{array}$ & $127.47 \pm 1.33^{\mathrm{a}}$ & $\begin{array}{c}83.33 \pm \\
2.59^{\mathrm{b}}\end{array}$ & $\begin{array}{c}17.60 \pm \\
1.48^{\mathrm{a}}\end{array}$ & $\begin{array}{c}126.42 \pm \\
1.38^{\mathrm{a}}\end{array}$ & $\begin{array}{c}72.55 \pm \\
2.54^{c}\end{array}$ & $\begin{array}{c}171.39 \pm \\
1.46^{\mathrm{a}}\end{array}$ & $\begin{array}{c}2.77 \pm \\
0.18^{\mathrm{a}}\end{array}$ & $\begin{array}{c}3.30 \pm \\
0.27^{\mathrm{a}}\end{array}$ & $\begin{array}{c}0.61 \pm \\
0.02^{\mathrm{b}}\end{array}$ & $\begin{array}{c}3.64 \pm \\
0.11^{\mathrm{a}}\end{array}$ \\
\hline $\mathrm{F} 2$ & $\begin{array}{c}204.02 \pm \\
6.80^{\mathrm{a}}\end{array}$ & $199.21 \pm 9.96^{c}$ & $\begin{array}{l}75.60 \pm \\
4.53^{\mathrm{b}}\end{array}$ & $\begin{array}{c}17.99 \pm \\
3.40^{\mathrm{a}}\end{array}$ & $\begin{array}{c}133.43 \pm \\
0.86^{\mathrm{bc}}\end{array}$ & $\begin{array}{c}70.48 \pm \\
2.71^{\mathrm{c}}\end{array}$ & $\begin{array}{c}187.59 \pm \\
7.41^{\mathrm{b}}\end{array}$ & $\begin{array}{c}2.70 \pm \\
0.15^{\mathrm{a}}\end{array}$ & $\begin{array}{c}2.76 \pm \\
0.37^{\mathrm{a}}\end{array}$ & $\begin{array}{c}0.46 \pm \\
0.02^{\mathrm{a}}\end{array}$ & $\begin{array}{c}3.74 \pm \\
0.26^{\mathrm{a}}\end{array}$ \\
\hline F3 & $\begin{array}{c}202.94 \pm \\
7.24^{\mathrm{a}}\end{array}$ & $184.05 \pm 4.13^{\mathrm{c}}$ & $\begin{array}{c}85.76 \pm \\
1.62^{\mathrm{b}}\end{array}$ & $\begin{array}{c}16.27 \pm \\
3.17^{\mathrm{a}}\end{array}$ & $\begin{array}{c}138.84 \pm \\
0.72^{\mathrm{b}}\end{array}$ & $\begin{array}{c}58.91 \pm \\
2.04^{\mathrm{a}}\end{array}$ & $\begin{array}{c}206.16 \pm \\
6.07^{c}\end{array}$ & $\begin{array}{c}2.47 \pm \\
0.14^{\mathrm{a}}\end{array}$ & $\begin{array}{c}2.73 \pm \\
0.33^{\mathrm{a}}\end{array}$ & $\begin{array}{c}0.42 \pm \\
0.03^{\mathrm{a}}\end{array}$ & $\begin{array}{c}5.70 \pm \\
0.28^{\mathrm{b}}\end{array}$ \\
\hline
\end{tabular}

Copyright@ Michelle CF Djouhou | Biomed J Sci \& Tech Res | BJSTR. MS.ID.004693. powder does not negatively impact dietary protein utilization and liver synthesis.

\section{Serum Biochemical Parameters}

Serum level glucose, triglyceride, total cholesterol, HDLcholesterol and LDL-cholesterol content of broiler chicken is presented in Table 4. In the same table, ALT, AST activities, albumin, globulin, creatinine and urea content are also specified. There is a variability in the serum triglyceride content after Moringa oleifera consumption. Consumption of increasing amounts of $M$. oleifera leaf powder did influence HDLc and LDLc levels $(\mathrm{P}<0.05)$; however, the LDLc level in control chickens was significantly higher than in the experimental groups $(\mathrm{p}<0.05)$. Subsequently, consumption of Moringa leads to a decrease in LDLc content. These results agree with those of several authors who, incorporating leaves of other plants such as neem (Azadirachta indica) in broiler's and rabbit's feed and noted their hypocholesterolemic effects. They attributed these effects to the presence of several compounds such as polyphenols in these leaves. A significant decrease in serum total cholesterol compared to the control was noted following the consumption of Moringa leaf powder. This can be explained on one hand by the presence in M. oleifera leaves of phytochemical compounds such as alkaloids and saponins which have anticholesterolemic activities and on the other hand by its high content of fibres which bind to cholesterol and prevent its intestinal absorption resulting in a decrease in the levels of total cholesterol and LDL cholesterol. Indeed, insoluble fibres have the ability to bind to bile acids reducing the absorption of fats and cholesterol. Similar results were obtained by Abdel-Azeem, Mohamed, ElShiekh \& Hessin (2017) who showed that the cholesterol and LDL cholesterol levels decreased following consumption of Moringa leaf powder. 
Feeding rations containing Moringa leaf powder has no negative effect on liver function as all values are within the normal range established by Harr (2002). However, between groups there are differences ranging from slightly to highly significant in transaminase (ALT and AST) levels. Consumption of Moringa leaves leads to a significant decrease in the AST content $(\mathrm{p}<0.05)$; it can be concluded that no deterioration of liver function was noted. The creatinine content is higher in the control group serum and lower in the serum of chickens fed with M. oleifera leaf powder although the values do not indicate impaired kidney function. Creatinine, a degradation product of creatine, is eliminated by the kidneys. Thus, an increase in creatinine or serum urea reflects a decrease in glomerular filtration rate. Urea, on the other hand, is a nitrogenous waste product of protein degradation in the liver, filtered by the kidneys. Elevated blood urea levels may indicate renal impairment or protein hyper catabolism. The urea values in this study are within the normal range of 4.80 to $19.80 \mathrm{mg} / \mathrm{dL}$ reported by Kaneko, Harvey \& Bruss (1997) for birds.

\section{Proximal Composition}

No significant differences ( $p>0.05$ ) were observed in ash and carbohydrate content of muscle of broiler chicken due to Moringa leaf powder supplementation. While there were important variations in moisture, lipid and protein content. Results are presented in Figure 4. Chicken flesh from F0 and F3 treatments contains much more water than that of chickens from treatments F1 and F2 $(\mathrm{P}<0.05)$. The consumption of Moringa oleifera leaf powder did not influence $(\mathrm{P}>0.05)$ ash and sugar content of the flesh. Subjects consuming the Moringa-free ration have the lowest protein content. The increase in the protein content of the chicken meat of F1, F2 and F3 groups could be due to the nutritional richness of their feed compared to F0 feed. Indeed, the first three rations contain more protein and fat than the last one (F0). Although the water and protein content are much lower than those of the breast of Brazilian Cobb chickens found by Brasil et al (2018), the ash and lipid contents are higher. The lipid content is inversely proportional to the percentage of Moringa leaf powder incorporation. The lowfat content of chicken meat is a real advantage even though chicken is a white meat. Numerous studies and extensive media coverage have been carried out over the last decade regarding food health and safety issues. Meat has been shown to be a major dietary source of saturated fatty acids which have been implicated in the increased risk of coronary heart disease, diabetes mellitus, stroke and some cancers. Meat consumers are therefore concerned about the composition of meat fat; the lower the fat content of a meat, the more it would be appreciated by the consumer.

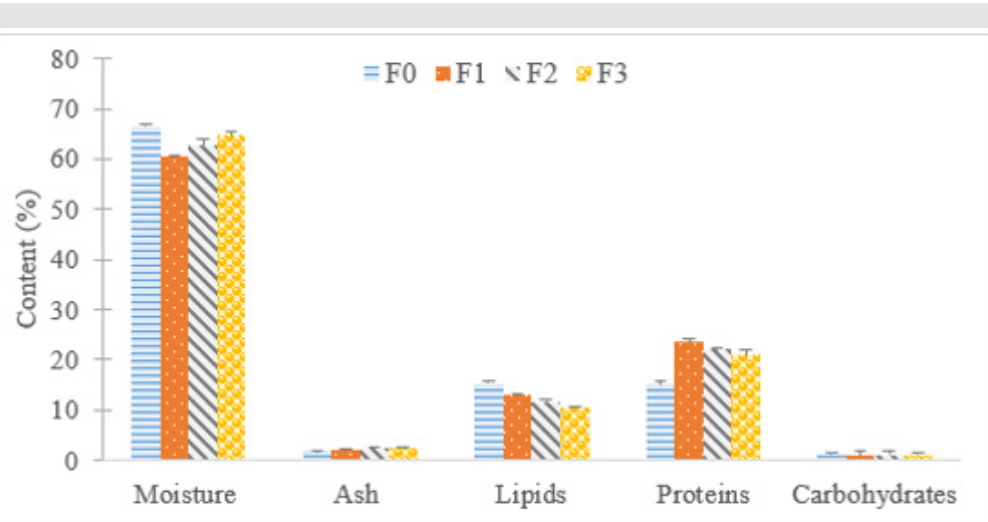

Figure 4: Effect of Moringa oleifera leaf powder supplementation on proximal composition (\%) of broiler chicken meat.

\section{Chicken Meat Thiol Composition}

The determination of total, oxidised and reduced glutathione levels as well as total thiol content of the edible meat of chickens was carried out and the results are presented in Table 5. The increased levels of glutathione and total thiols in the flesh of chickens fed with M. oleifera leaf powder improves the quality of the meat by offering

Table 5: Effect of Moringa oleifera powder incorporation on thiol levels ( $\mu$ mol-g-1) in chicken flesh. the consumer a product with a high antioxidant value in contrast to the control group flesh. Indeed, the high prevalence of thiols in a food improves its antioxidant potential due to their reducing power and their ability to react with free radicals. The glutathione levels in this study are higher than those of Zhang et al. (2015) and Pusic et al. (2018) who had mean levels of 24.18 and $29.75 \mu$ mol-g-1 respectively in the pectoral muscle of Cobb 500 broilers.

\begin{tabular}{|c|c|c|c|c|}
\hline & Total GSH & GSSG & Reduced GSH & Total thiols \\
\hline F0 & $36.11 \pm 1.94^{\mathrm{a}}$ & $6.66 \pm 0.52^{\mathrm{b}}$ & $29.45 \pm 1.42^{\mathrm{a}}$ & $74.73 \pm 1.28^{\mathrm{a}}$ \\
\hline F1 & $55.59 \pm 2.44^{\mathrm{b}}$ & $3.45 \pm 0.37^{\mathrm{a}}$ & $52.14 \pm 2.07^{\mathrm{b}}$ & $85.25 \pm 0.72^{\mathrm{b}}$ \\
\hline F2 & $57.00 \pm 2.33^{\mathrm{b}}$ & $4.47 \pm 0.29^{\mathrm{a}}$ & $52.53 \pm 2.61^{\mathrm{b}}$ & $86.04 \pm 0.20^{\mathrm{b}}$ \\
\hline F3 & $54.91 \pm 0.10^{\mathrm{b}}$ & $2.96 \pm 0.49^{\mathrm{a}}$ & $51.95 \pm 0.59^{\mathrm{b}}$ & $87.55 \pm 0.45^{\mathrm{b}}$ \\
\hline
\end{tabular}




\section{Conclusion}

From the present study, it can be concluded that dietary supplementation with Moringa leaf powder up to $8 \%$ in broiler chicken improve feed conversion ratio, meat proximal composition and total glutathione content. It decreases the mortality rate and glutathione S-transferase activity. This supplementation at low rate also increases feed intake. Therefore, Moringa oleifera leaf powder can be used as nutrient source in broiler chicken feed to stimulate their metabolism and antioxidant defence.

\section{Acknowledgement}

Authors thank their respective laboratories for their support and Ms Kasop Elisabeth for her assistance during experimental follow up. They are also thankful to Pr Sephirin Djiogue from Department of Animal Biology and Physiology, Laboratory of Animal Physiology, Faculty of Science, The University of Yaoundé I, for his assistance during laboratory analysis.

\section{Conflict of Interest}

The authors declare that there are no conflicts of interest. The authors alone are responsible for the content and writing of this article.

\section{Funding}

This research received no specific grants from any funding agency in the public, commercial or not-for-profit sectors.

\section{References}

1. Abdel Azeem AF, Mohamed FA, El Shiekh SEM, Hessin AF (2017) Maximizing productivity of Lohmann chickens by feeding diets inclusion different levels of Moringa oleifera leaf powder as a safe feed additive. Journal of Animal and Poultry Production 8(8): 319-328.

2. Abdulla MA, Ahmed KAA, Al Bayaty FH, Masood Y (2010) Gastroprotective effect of Phyllanthus niruri leaf extract against ethanol-induced gastric mucosal injury in rats. African Journal of Pharmacy and Pharmacology 4(5): 226-230.

3. Abouelfetouh AY, Moussa NK (2012) Enhancement of antimicrobial activity of four classes of antibiotics combined with garlic. Asian Journal of Plant Sciences 11: 148-152.

4. Alam M, Anjum A (2003) Effect of sulphur on blood picture of Fayoumi chickens. Veterinarski Arhiv 73(1): 39-46.

5. Anderson ME (1985) Determination of glutathione and glutathione disulphide in biological samples. In: Meister A (Eds.), Glutamate, glutamine, glutathione, and related compounds. Methods Enzymology 113: 548-555.

6. (1980) AOAC. Official methods of analysis of the Association of Official Analytical Chemists, (13 ${ }^{\text {th }}$ edn.), Association of Official: Washington DC, USA.

7. Aouacheri W, Saka S, Djafer R (2009) L'effet toxique d'un insecticide (alphaméthrine) sur l'activité du système enzymatique de détoxification du glutathion. Annales de Toxicologie Analytique 21(3): 125-129.

8. Ashong JO, Brown DL (2011) Safety and efficacy of Moringa oleifera powder for growing poultry. Journal of Animal Science 89(Suppl 1): 84 220.
9. Bonsu FRK, Kagya Agyemang, JK, Kwenin, WKJ, Zanu HK (2012) Medicinal response of broiler chickens to diets containing neem (Azadirachta indica) leaf meal, haematology and meat sensory analysis. World Applied Sciences Journal 19: 800-805.

10. Bourely J (1982) Observation sur le dosage de l'huile des graines de cotonnier. Coton et Fibres Tropicales 27(2): 183-196.

11. Bradford MM (1976) A rapid and sensitive method for the quantification of microgram quantities of protein utilizing the principle of protein-dye binding. Analytical Biochemistry 72: 248-254.

12. Brasil R, Lima C, Machado N, Curvello F, Quaresma D (2018) Digestible lysine requirements the performance, carcass traits and breast meat quality of slow-growing broilers. Brazilian Journal of Poultry Science 20(3): 555-564.

13. Crawford GI (2015) Managing sulfur concentrations in feed and water In: Proceeding of the Minnesota nutrition conference St. Paul pp. 80-93.

14. DanMalam HU, Abubakar Z, Katsayal UA (2001) Pharmacognostic studies on the leaves of Moringa oleifera. Nigerian Journal of Natural Product and Medicine 5: 45-49.

15. Djakalia B, Guichard BL, Soumaila, D (2011) Effect of Moringa oleifera on growth performance and health status of young post-weaning rabbits. Journal of Poultry Sciience 4(1): 7-13.

16. Dubois M, Gilles KA, Hamilton JK, Rebers PA, Smith E (1956) Colorimetric method for determination of sugars and related substances. Agricultural Research Service 28(3): 350-356.

17. Egu UN (2019) Effect of graded levels of Moringa oleifera leaf meal on performance and serum biochemical parameters of broiler chickens. Journal of Animal Science and Veterinary Medicine 4(1): 1-8.

18. El Hack ME, Alagawany M, Elrys AS, Desoky EM, Tolba HM (2018) Effect of Forage Moringa oleifera L. (moringa) on Animal Health and Nutrition and Its Beneficial Applications in Soil, Plants and Water Purification. Agriculture 8: 145.

19. Fahey JW (2005) Moringa oleifera: A review of the medical evidence for its nutritional, therapeutic, and prophylactic properties. Part 1 . Trees for Life Journal 1: 5.

20. Fatima S, Mahmood R (2007) Vitamin C attenuates potassium dichromate-induced nephrotoxicity and alterations in renal brush border membrane enzymes and phosphate transport in rats. Clinica Chimica Acta, 386(1-2): 94-99.

21. Foidl N, Makkar HPS, Becker K (2001) The potential of Moringa oleifera for agricultural and industrial uses. In Fuglie LJ (eds.). The miracle tree: the multiple attributes of Moringa. Centre Technique de Coopération Agricole et Rurale / Church World Service. Dakar Sénégal p. 45-76.

22. Gakuya DW, Mbugua PN, Mwaniki SM, Kiama SG, Muchemi GM (2014) Effect of supplementation of Moringa oleifera (LAM) leaf meal in layer chicken feed. International Journal of Poultry Science 13(7): 379-384.

23. Habig WH, Pabst MJ, Jacoby WB (1974) Glutathione S-transferases: the first enzymatic step in mercapturic acid formation. The Journal of Biological Chemistry 249(22): 7130-7139.

24. Harr KE (2002) Clinical chemistry of companion avian species: A review. Veterinary Clinical Pathology, 31(3): 140-151.

25. Jaturasitha ST, Srikanchai M, Kreuzer, Wicke M (2008) Differences in carcass and meat characteristics between chicken indigenous to Northern Thailand (black-boned and thai native) and imported extensive breeds (bresse and rhode island red). Poultry Science 87(1): 160-169.

26. Joshi P, Mehta D (2010) Effect of dehydration on the nutritive value of drumstick leaves. Journal of Metabolomics and Systems Biology 1(1): 5-9.

27. Kaneko JJ, Harvey JW, Bruss HI (1997) Clinical Biochemistry of Domestic Animals. In Kaneko JJ, Harvey JW, Bruss HI(Eds.), (5 ${ }^{\text {th }}$ Edn.), Academic Press, San Diego, Carlifonia, pp. 885-905. 
28. Khan I, Zaneb H, Masood S, Youaf MS, Rehman HF (2017) Effect of Moringa oleifera leaf powder supplementation on growth performance and intestinal morphology in broiler chickens. Journal of Animal Physiology and Animal Nutrition 1(Suppl 1): 114-121.

29. Khan S, Sardar R, Anjum MA (2007) Effects of dietary garlic on performance and serum and egg yolk cholesterol concentration in laying hens. Asian Journal of Poultry Science 1: 22-27.

30. Lewandowska M, Sirko A (2008) Recent advances in understanding plant response to sulfur-deficiencystress. Acta Biochemica Polonica 55(3): 457-471.

31. Lu W, Wang J, Zhang HJ, Wu SG, Qi GH (2016) Evaluation of Moringa oleifera leaf in laying hens: effects on laying performance, egg quality, plasma biochemistry and organ histopathological indices. Italian Journal of Animal Science 15(4): 658-665.

32. Ogbuewu IP, Okoro VM, Okoli IC, Iloeje MU (2011) Evaluation of dried leaf meal of an ethnomedicinal plant-neem on linear growths and reproductive tract morphometry of rabbit does. Electronic Journal of Environmental, Agricultural and Food Chemistry 10: 2153-2159.

33. Oloyede OB, Odutuga AA, Minari JB, Amballi AA (2007) Assessment of some serum metabolites and enzymes of broiler-chickens fed raw and processed Bambara groundnut. International Journal of Poultry Science 6(9): 647-650.

34. Olugbemi TS, Mutayoba SK, Lekule FP (2010) Effect of Moringa (Moringa oleifera) inclusion in cassava-based diets fed to broiler chickens. International Journal of Poultry Science 9(4): 363-367.

35. Palego L, Betti L, Giannaccini G (2015) Sulfur metabolism and sulfurcontaining amino acids: Molecular effectors. Biochemical Pharmacology 4(7): 1-8.

36. Panda SK, Panda AK, Tanuja S, Mohanty A, Panigrahy KK (2017) Effect of dietary supplementation of fermented fish silage on serum-biochemical parameters of broiler Japanese quails (Coturnix japonica). Veterinary World 10(4): 380-385

37. Rafiullah P, Sajid A (2011) Effect of feed additives on the performance of broilers. ARPN Journal of Agricultural and Biological Science 6: 66-71.

38. Pusic I, Ljubic BB, Lazarus MV, Radin L, Janjecic Z (2018) Dietary organic selenium supplementations affect oxidative stability of chilled and frozen chicken meat. Journal of Food and Nutrition Research 57(3): 274 283.

39. Romão PRT, Tovar J, Fonseca SG, Moraes RH, Cruz AK (2006) Glutathione and the redox control system trypanothione/trypanothione reductase are involved in the protection of Leishmania spp. against nitrosothiolinduced cytotoxicity. Brazilian Journal of Medical and Biological Research 39: 355-363.

40. Samarth VR, Dakshinkar NP, Jagtap DG, Bhojne GR (2003) Effect of Aswagandha (Withania somnifera) on haemato-biochemical profile of broilers. Indian Journal of Animal Sciences 73: 648-649.

41. Sedlak J, Lindsay RH (1968) Estimation of total, protein-bound, and non-protein sulfhydryl groups in tissue by Ellman's reagent. Analytical Biochemistry 25(1): 192-208

42. Sieh D, Watanabe M, Devers EA, Brueckner F, Hoefgen R (2013) The arbuscular mycorrhizal symbiosis influences sulfur starvation responses of Medicago truncatula. New Phytologist 197(2): 606-616.

43. Stohs SJ, Hartman MJ (2015) Review of the Safety and Efficacy of Moringa oleifera. Phytotherapy Research 29(6): 796-804.

44. Walker P, Rhubart Berg P, McKenzie S, Kelling K, Lawrence RS (2005) Public health implications of meat production and consumption. Public Health Nutrition 8(4): 348-356.

45. Wang S, Cawthon D, Bottje WG (1998) Age-related changes of plasma glutathione and cysteine in broilers: effect of dithiothreitol reduction vitro on free and bound pools. Poultry Science 77(8): 1234-1240.

46. Weckbercker G, Cory JG (1988) Ribonucleotide reductase activity and growth of glutathione-depended mouse leukaemia L 1210 cells in vitro. Cancer Letters 40(3): 257-264.

47. Wu G, Fang YZ, Yang S, Lupton JR, Turner ND (2004) Glutathione metabolism and its implications for health. The Journal of Nutrition 134(3): 489-492.

48. Yang RY, Chang LC, Hsu JC, Weng BBC, Palada MC (2006) Propriétés nutritionnelles et fonctionnelles des feuilles de Moringa. Du germoplasme, à la plante, à l'aliment et à la santé (1-9). In : Moringa et autres végétaux à fort potentiel nutritionnel : Stratégies, normes et marchés pour un meilleur impact sur la nutrition en Afrique : 16-18.

49. Yassa HD, Tohamy AF (2014) Extract of Moringa oleifera leaves ameliorates streptozotocin-induced Diabetes mellitus in adult rats. Acta Histochemica 116(5): 844-854.

50. Zhang J, Hu Z, Lu C, Bai K, Zhang L (2015) Effect of various levels of dietary curcumin on meat quality and antioxidant profile of breast muscle in broilers. Journal of Agricultural and Food Chemistry 63(15): 3880-3886

ISSN : 2574-1241

DOI: $10.26717 /$ BJSTR.2020.28.004693

Michelle CF Djouhou. Biomed J Sci \& Tech Res

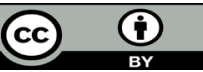

This work is licensed under Creative

Commons Attribution 4.0 License

Submission Link: https://biomedres.us/submit-manuscript.php

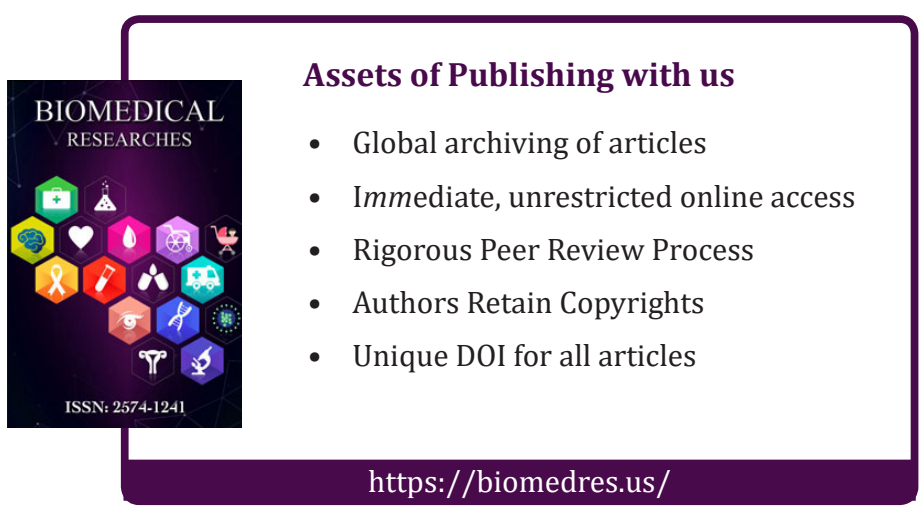

Copyright@ Michelle CF Djouhou | Biomed J Sci \& Tech Res | BJSTR. MS.ID.004693. 